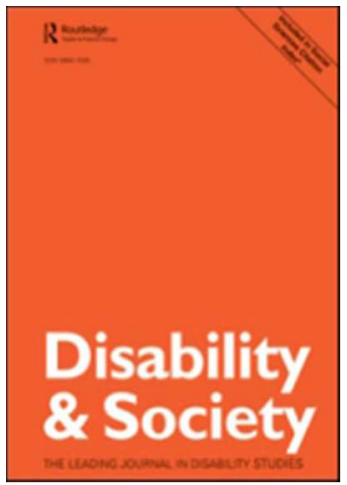

\title{
The Role of Neighborhood Physical Environment on Mobility and Social Participation among People using Mobility Assistive Technology
}

\begin{tabular}{|c|l|}
\hline Journal: & Disability \& Society \\
\hline Manuscript ID & CDSO-2017-0188.R2 \\
\hline Manuscript Type: & Original Article \\
\hline Keywords: & $\begin{array}{l}\text { mobility, social participation, neighborhood, mobility assistive technology, } \\
\text { systematic review, PRISMA protocol }\end{array}$ \\
\hline Abstract: & $\begin{array}{l}\text { This paper presents a systematic literature review on the impact of the } \\
\text { neighborhood physical environment on mobility and social participation } \\
\text { among people using mobility assistive technology (MAT). Peer-reviewed } \\
\text { articles from eight databases published in French or English from 1990 to } \\
\text { 2016 were searched. Thirty studies were included in this review. Factors } \\
\text { related to neighborhood environmental features, mobility in transit, and } \\
\text { accessibility of homes and public buildings influenced mobility and social } \\
\text { participation of MAT users. The majority of reviewed studies combined } \\
\text { different types of MAT, which made the interpretation of the results } \\
\text { challenging. Few studies included walker, cane, and crutch users. } \\
\text { Definitions of mobility and social participation lacked consistency and were } \\
\text { often simplistic. Future empirical research needs to examine the impact of } \\
\text { neighborhood physical environment factors separately for different MAT } \\
\text { users. Causality and links between mobility and social participation of } \\
\text { different MAT users at the neighborhood level should be further explored. }\end{array}$ \\
\hline
\end{tabular}

\section{SCHOLARONE \\ Manuscripts}

Bigonnesse C, Mahmood A, Chaudhury, H, Mortenson WB, Miller WC, Martin Ginis, KA.

Published: April 19, 2018 


\section{The Role of Neighborhood Physical Environment on Mobility and Social Participation among People using Mobility Assistive Technology}

\section{Points of Interest}

- This article looks at the influence of the neighbourhood physical environment on the mobility and social participation of people with mobility disability.

- Current research does not provide a clear answer on how neighbourhood aspects like land-use or residential density influence the mobility or social participation of people with mobility disability.

- People with mobility disability face many obstacles to both their mobility and social participation while they are in transit to a destination, when they visit the homes of family and friends, and when they access public buildings.

- Current research rarely includes people using walkers, canes, or crutches compared to wheelchair and scooter users.

- More research should be done with people using specific types of mobility assistive technology in order to design neighbourhoods that will support their mobility and social participation. 


\section{Introduction}

Mobility is a prerequisite to carry out daily activities and to participate in society (Brandt, Iwarsson, and Ståhle 2004; Latham et al. 2009; Lord and Luxembourg 2006; Vine, Buys, and Aird 2012). Therefore, mobility disability can greatly impact one's level of functioning and independence. Worldwide prevalence of mobility disability is difficult to ascertain due to gaps in international data (World Health Organization 2011). Nevertheless, the WHO estimates that between $15.6 \%$ and $19.4 \%$ of people 15 years of age and older are living with disability worldwide (World Health Organization 2011). According to the World Health Survey, 7.2\% of respondents reported having severe or extreme difficulty moving around (World Health Organization 2011). In comparison, $7.2 \%$ of Canadians and $13.1 \%$ of Americans have a mobility disability which limits their daily activities (Statistics Canada 2016; Centers for Disease Control and Prevention 2016).

Many people living with a mobility disability use mobility assistive technology (MAT) (e.g., powered wheelchairs, manual wheelchairs, scooters, walkers, canes, crutches) to get around and to assist them in performing their routine activities, thus enhancing their mobility and social participation (Auger et al. 2008; Barker, Reid, and Cott 2006; Hjelle and Vik 2011; Löfqvist et al. 2012; Statistics Canada 2015). For instance, about 3 million North Americans 15 years of age and older are wheelchair or scooter users (LaPlante and Kaye 2010; Giesbrecht et al. 2017).

Multiple environmental factors influence the mobility and social participation of people with various types of disability (Hammel et al. 2015; Hanson et al. 2013; Rosso, Auchincloss, and Michael 2011; World Health Organization 2011). Mobility and social participation are closely related. Mobility is defined as the physical movement from one point to another through various means such as walking with or without MAT, automobiles, or public transportation 
(Latham et al. 2009; Lord and Luxembourg 2006; Vine, Buys, and Aird 2012). Social participation is defined as performing everyday activities and being part of the life of the community (Baum 2011; Chang, Coster, and Helfrich 2013; Levasseur et al. 2010). The home environment and the physical environment close to home (2-3 city blocks or $1 / 4$ mile) are strongly associated with the mobility and social participation of people with mobility disability in particular (Chaudhury et al. 2016; Clarke, Ailshire, and Lantz 2009; Clarke et al. 2011; Cooper et al. 2011; Williams and Willmott 2012).

Although empirical research in this area is growing, there is limited knowledge surrounding the barriers and facilitators to mobility and social participation that are encountered in the neighborhood physical environment by MAT users (Botticello, Rohrbach, and Cobbold 2015; Clarke 2014; Harris, Yang, and Sanford 2015). Understanding the opportunities and constraints afforded by the neighborhood physical environment is central to understanding the mobility and social participation of this population, and could inform interventions and policies to foster independence, health, and well-being of MAT users, as well as contribute to the emergent literature about enabling environments (O'Brien 2014; Gibson et al. 2012; Duff 2009; Hansji, Wilson, and Cordier 2015).

To provide a synthesis of the current knowledge in this area and inform future empirical studies, this paper presents a systematic literature review on the association between neighborhood physical environment, mobility, and social participation among MAT users. Using the Preferred Reporting Items for Systematic Reviews and Meta-Analyzes protocol (PRISMA) (Liberati et al. 2009; Moher et al. 2009), this review was guided by the question: what is the impact of the neighborhood physical environment on mobility and social participation of MAT users? 


\section{Methods}

A search for articles in English and French from January 1990 to January 2016 was conducted in the Web of Science database and in seven EBSCO specialized databases: Academic Search Premier, AgeLine, CINAHL, Humanities \& Social Sciences, Medline, Social Sciences, Sport Discuss. The following keywords were used: mobility, participation, disability, disabled people, people with disabilities, neighborhood, physical environment, built environment, social environment, public buildings, home environment, mobility aids, assistive devices, mobility devices, mobility assistive technology, walking aids, wheelchair, power wheelchair, scooter, walker, cane, crutches, barrier-free environment, visitability, universal accessibility, universal design, connectivity, and walkability. Duplicates were automatically removed by the search system in each database.

\section{Selection Process}

To be included, studies were required to: 1) be peer-reviewed articles (quantitative, qualitative, or mixed methods) written in English or French; 2) include participants 18 years of age and older and users of at least one of the following mobility assistive technologies: manual wheelchair, powered wheelchair, scooter, walker, cane, and crutches; and 3) address the topic of neighborhood physical environment and mobility and/or social participation among people using MAT. Studies were excluded if they: 1) included participants with hearing, visual, mental, or intellectual impairment; 2) were systematic reviews or policy and program evaluations; 3) used definitions of mobility and social participation that did not match the preselected definitions.

Mobility was defined as physical movement from one point to another through various means such as walking with or without MAT, automobiles, or public transportation to meet daily needs and activities (Latham et al. 2009; Lord and Luxembourg 2006; Webber, Porter, and 
Menec 2010). The neighborhood physical environment was defined using Webber et al.'s (2010) theoretical framework on mobility (Webber, Porter, and Menec 2010). The mobility zones of the home (e.g., house, apartment, institution), the outdoor area surrounding the home (e.g., yard, parking lot), the neighborhood (e.g., nearby streets or parks), and the service community (e.g., shops, banks, health care facilities) were selected to operationalize the concept of "neighborhood physical environment." Social participation was defined using the social participation taxonomy developed by Levasseur et al. (2010). Levasseur et al.'s (2010) taxonomy includes different types of social participation based on individual proximity of involvement with others (i.e., alone, in parallel, or in interaction) and the goals of the activity (i.e., basic needs oriented, socially oriented, task oriented, oriented toward helping others, and society oriented). Consequently, articles using definitions with one or multiple aspects of social participation found in this taxonomy were included.

Articles were initially screened by the first three authors for eligibility by titles and abstracts, and subsequently validated by the rest of the authors. In case of doubt regarding the inclusion or exclusion of a particular study, an independent review of the study was undertaken by the first three authors, followed by a discussion until consensus regarding its exclusion or inclusion was reached. The EBSCO databases search yielded 1,594 records and the Web of Science search yielded 20 records. After a first exclusion process of reviewing titles and/or abstracts, 132 records were screened and 58 articles were reviewed in detail (sample, mobility and social participation operationalization, list of references). Twenty-eight additional articles were eliminated because participants did not use MAT, the definition of mobility was inappropriate (e.g., residential mobility), or because physical environment factors were absent 
from the findings. Figure 1 shows two examples of keyword combinations (Boolean search) used for this review.

[Figure 1 near here]

\section{Data Extraction and Analysis}

After reading the abstracts, articles were categorized according to device use and study methods. Then, characteristics of the studies including study purpose, methodology, methods, measurement (if applicable), sample size, sampling strategies, sample characteristics (age, type of MAT), and limitations were extracted into a table. Next, the results section of each study was analyzed to identify neighborhood physical environment factors and whether they were serving as barriers or facilitators to mobility and social participation among MAT users. Finally, thematic analysis was used to identify factors of the neighborhood physical environment (Braun and Clarke 2006). The factors were grouped into categories through an iterative process.

\section{Description of the Reviewed Studies}

Thirty articles were included in the final review and were published between 2002 and 2015 (see Table 1 for study details). Fifteen studies were from the United States, six studies were from Canada, six from Northern Europe (Sweden, Denmark, Norway), two from the United Kingdom, and one from Australia. Regarding the characteristics of the sample, fifteen studies focused on participants using manual and/or power wheelchairs, one focused solely on scooter users (Fomiatti et al. 2014), and the remaining fourteen studies focused on combinations of MAT. Fourteen studies used a sample of participants aged 50 years old and older and the remaining 16 studies used a sample of participants aged 18 years old and older. 
Fourteen studies were quantitative, eight were qualitative, and eight were based on mixed methods. For the quantitative studies, the smallest sample size was 16 participants (Cooper et al. 2011) and the largest sample size was 70,311 participants (LaPlante and Kaye 2010). Five studies were cross-sectional (Botticello, Rohrbach, and Cobbold 2014; Brandt, Iwarsson, and Ståhle 2004; Harris, Yang, and Sanford 2015; Liang et al. 2008; Pettersson et al. 2015), four studies used longitudinal designs (i.e., multi-cohort study, cohort study, or panel survey) (Auger et al. 2010; Hoenig et al. 2003; LaPlante and Kaye 2010; Meyers et al. 2002), and three studies used a combination of surveys and data loggers installed on the participants' wheelchairs (i.e., prospective observational study design) (Cooper et al. 2011; Karmarkar et al. 2011; Tolerico et al. 2007). Finally, one quantitative study was a randomized clinical trial, and one used multiple stage survey as their methods (Carlson and Myklebust 2002; Hoenig et al. 2007).

For the qualitative studies, the sample size varied from six (Hjelle and Vik 2011) to 35 participants (Rosenberg et al. 2013). All studies used semi-structured or in-depth interviews for their data collection methods except for two, which used focus groups (Hedberg-Kristensson, Ivanoff, and Iwarsson 2007; Hjelle and Vik 2011). For the mixed-methods studies, the sample size varied from three (Kylberg et al. 2013; Löfqvist et al. 2009) to 6,578 participants (Clarke 2014). Four studies used a combination of surveys and semi-structured interviews or focus groups, and two studies used a case study methodology (Kylberg et al. 2013; Löfqvist et al. 2009).

Twelve studies focused on mobility (Bromley, Matthews, and Thomas 2007; Clarke 2014; Gell et al. 2015; Gonzalez and Lord 2015; Harris, Yang, and Sanford 2015; Hoenig et al. 2007; Kirchner, Gerber, and Smith 2008; Korotchenko and Hurd Clarke 2014; LaPlante and Kaye 2010; Löfqvist et al. 2009; Matthews et al. 2003; Meyers et al. 2002) and seven studies 
focused on social participation (Botticello, Rohrbach, and Cobbold 2014; Cooper et al. 2011;

Karmarkar et al. 2011; Kylberg et al. 2013; Pettersson et al. 2015; Tolerico et al. 2007; Wee and Lysaght 2009). The remaining eleven studies focused on both mobility and social participation (Auger et al. 2010; Barker, Reid, and Cott 2006; Brandt, Iwarsson, and Ståhle 2004; Carlson and Myklebust 2002; Fomiatti et al. 2014; Gibson et al. 2012; Hedberg-Kristensson, Ivanoff, and Iwarsson 2007; Hjelle and Vik 2011; Hoenig et al. 2003; Liang et al. 2008; Rosenberg et al. 2013).

A majority of the reviewed studies were of high quality, based on the Mixed Methods Appraisal Tool (MMAT) (Pluye et al. 2011). This tool is designed to assess the quality of mixed methods studies included in literature reviews. For each type of study (qualitative, quantitative, and mixed methods), the tool provides methodological quality criteria related to data collection methods, data analysis strategies, sampling, etc. A study that meets $100 \%$ of the MMAT criteria is of the highest quality, compared to a study that meets only $25 \%$ of the criteria is of lower quality. Of the reviewed studies, 16 met $100 \%$ of the MMAT criteria, ten met $75 \%$ of the criteria, and four met $50 \%$ of the criteria. The main issue among the studies with a score of $75 \%$ was related to sample composition (i.e., the sample was unrepresentative of the study population). The utilization of crude or non-validated measures and sample-related limitations were the primary issues among the reviewed studies with a score of $50 \%$ (See Table 1 for specific MMAT scores).

\section{[Table 1 near here]}

\section{Results}

This section, based on the results of the thematic analysis, presents the barriers to mobility and social participation found in three main areas: 1) neighborhood features, 2) mobility in transit, 
and 3) homes and public buildings. Table 2 provides an overview of the results of the themes found in the three areas for each type of MAT.

[Table 2 near here]

\section{Neighborhood Features}

On the one hand, reviewed studies indicated that some features of the neighborhood are associated with increased social participation among MAT users. For instance, safe neighborhoods (i.e., low crime rate, being able to obtain assistance in case of need) with open spaces such as forests, wetlands, cultivated farms, and waterfront (Botticello, Rohrbach, and Cobbold 2014) facilitated social participation among people using manual and power wheelchairs, walkers, and canes (Gibson et al. 2012; Liang et al. 2008; Rosenberg et al. 2013). One study showed an association between proximity of accessible places and destinations that fostered social engagement (e.g., friends and family homes) and contributed to day to day living (i.e., restaurants, grocery shops, and banks) and social participation among people using wheelchairs (Gibson et al. 2012).

On the other hand, the findings on the role of neighborhood features were mixed in some aspects. For instance, mixed land-use and residential density were identified as barriers to social participation among wheelchair users (Botticello, Rohrbach, and Cobbold 2014). Those findings are consistent with Cooper et al. (2011), who found that travel speed is associated with community participation among manual wheelchair users, suggesting that crowded and busy areas could limit mobility. Other studies showed no association between street connectivity, residential density, and mixed land-use and mobility or social participation among wheelchair and scooter users (Auger et al. 2010; Liang et al. 2008). Finally, only one study found a relationship between neighborhood features and mobility among MAT users. Gell et al. (2015) 
found a positive association between walkability, residential density, and street connectivity and mobility of people using canes, walkers, and manual wheelchairs aged 50 and over. They found no link between crime rate and mobility.

\section{Mobility in Transit}

This section covers obstacles present in the neighborhood that MAT users encounter while in transit from one place to another.

\section{Weather}

Twelve of the 30 articles reported "weather conditions" as a barrier to mobility among people using MAT. More precisely, nine studies identified "weather conditions" as barriers for manual and power wheelchairs (Barker, Reid, and Cott 2006; Brandt, Iwarsson, and Ståhle 2004; Gibson et al. 2012; Gonzalez and Lord 2015; Hedberg-Kristensson, Ivanoff, and Iwarsson 2007; Kirchner, Gerber, and Smith 2008; Meyers et al. 2002; Rosenberg et al. 2013; Wee and Lysaght 2009), three for scooters (Fomiatti et al. 2014; Gonzalez and Lord 2015; Hoenig et al. 2007), and six for canes, walkers, and crutches (Gonzalez and Lord 2015; Hedberg-Kristensson, Ivanoff, and Iwarsson 2007; Hoenig et al. 2007; Kylberg et al. 2013; Löfqvist et al. 2009; Rosenberg et al. 2013). These "weather conditions" included heat, rain, wind, snow as well as weather-related conditions such as icy and slippery surfaces, puddles, poor drainage, and inadequate snow removal (Barker, Reid, and Cott 2006; Brandt, Iwarsson, and Ståhle 2004; Fomiatti et al. 2014; Gibson et al. 2012; Gonzalez and Lord 2015; Hoenig et al. 2007; Kirchner, Gerber, and Smith 2008; Löfqvist et al. 2009; Meyers et al. 2002; Rosenberg et al. 2013; Wee and Lysaght 2009). 


\title{
Sidewalk and Street Conditions
}

Fourteen of the articles stated that the "sidewalk and street conditions" impede mobility among all MAT users. "Uneven or narrow sidewalks" and "rough pavement" are among the most reported barriers (Barker, Reid, and Cott 2006; Bromley, Matthews, and Thomas 2007; Fomiatti et al. 2014; Harris, Yang, and Sanford 2015; Hjelle and Vik 2011; Hoenig et al. 2007; Kirchner, Gerber, and Smith 2008; Korotchenko and Hurd Clarke 2014; Kylberg et al. 2013; LaPlante and Kaye 2010; Matthews et al. 2003; Meyers et al. 2002; Pettersson et al. 2015; Rosenberg et al. 2013). Absent "curb cuts" or those that were too high, poorly designed or obstructed were problematic (Bromley, Matthews, and Thomas 2007; Harris, Yang, and Sanford 2015; Hoenig et al. 2007; Kirchner, Gerber, and Smith 2008; Korotchenko and Hurd Clarke 2014; Matthews et al. 2003; Meyers et al. 2002; Rosenberg et al. 2013).

The absence of crosswalks at key intersections and crosswalks that were poorly designed (i.e., not enough time to cross, inaccessible press buttons) were barriers to mobility for most MAT users, except those using crutches (Harris, Yang, and Sanford 2015; Kirchner, Gerber, and Smith 2008; Korotchenko and Hurd Clarke 2014; Matthews et al. 2003; Rosenberg et al. 2013). Even if sidewalks and pavement conditions were appropriate, "temporary obstacles" could act as barriers to mobility. Non-permanent or temporary obstacles such as café outdoor furniture, sandwich boards, and construction presented a major challenge to most MAT users, except those using crutches (Harris, Yang, and Sanford 2015; Hedberg-Kristensson, Ivanoff, and Iwarsson 2007; Kirchner, Gerber, and Smith 2008; Matthews et al. 2003; Rosenberg et al. 2013).

\author{
Traffic Congestion \\ "Traffic congestion," relating to both vehicular and pedestrian traffic was an important \\ barrier to the mobility of MAT users reported in nine studies. Vehicular traffic was reported as a
}


barrier for most MAT users except for those using crutches (Harris, Yang, and Sanford 2015; Matthews et al. 2003; Meyers et al. 2002; Rosenberg et al. 2013). Pedestrian traffic on sidewalks or public spaces was a problem for manual wheelchair users, power wheelchair users, and scooter users (Barker, Reid, and Cott 2006; Bromley, Matthews, and Thomas 2007; Fomiatti et al. 2014; Kirchner, Gerber, and Smith 2008; Matthews et al. 2003; Meyers et al. 2002). To overcome these barriers, some wheelchair and scooter users avoided going out during peak times and developed an intimate knowledge of the accessible roads they could use (Bromley, Matthews, and Thomas 2007; Fomiatti et al. 2014).

\section{Parking}

Many MAT users rely on driving or riding in private cars for their mobility needs (Brandt, Iwarsson, and Ståhle 2004; Carlson and Myklebust 2002; Gonzalez and Lord 2015; LaPlante and Kaye 2010). Consequently, the availability of parking is important to support mobility and social participation. The reviewed studies suggested that the lack of accessible parking is linked to mobility restrictions among most types of MAT users besides those using crutches (Bromley, Matthews, and Thomas 2007; Matthews et al. 2003; Rosenberg et al. 2013). Those mobility restrictions were also linked to social participation limitations among those using manual and power wheelchairs (Meyers et al. 2002).

\section{Public Transportation System}

An inadequate public transportation system was described as a barrier to both mobility (Bromley, Matthews, and Thomas 2007; Carlson and Myklebust 2002; Fomiatti et al. 2014; Gonzalez and Lord 2015; Korotchenko and Hurd Clarke 2014; LaPlante and Kaye 2010; Meyers et al. 2002) and social participation (Brandt, Iwarsson, and Ståhle 2004; Carlson and Myklebust 2002; Gibson et al. 2012; Hoenig et al. 2003; Kylberg et al. 2013; Meyers et al. 2002; 
Wee and Lysaght 2009) for most MAT users except for those using crutches. Problems with public transportation systems include insufficient space to maneuver in buses and trains for scooter, walker, and cane users (Fomiatti et al. 2014; Kylberg et al. 2013), incompatible schedules or absence of stops at desired destinations (Gibson et al. 2012; Gonzalez and Lord 2015; Korotchenko and Hurd Clarke 2014) for most MAT users except those with crutches, and inaccessible stops, stations, or buses and trains for all MAT users (Bromley, Matthews, and Thomas 2007; Hoenig et al. 2003; Korotchenko and Hurd Clarke 2014; LaPlante and Kaye 2010; Meyers et al. 2002).

\section{Homes \& Public Buildings}

This section covers the barriers to mobility and social participation found in the immediate home environment and at destinations including public buildings and the homes of family and friends.

\section{Immediate Home Environment: Threshold to Neighborhood}

Eight of the reviewed studies found a link between accessibility at the entrance of MAT users' residences and social participation (Barker, Reid, and Cott 2006; Carlson and Myklebust 2002; Clarke 2014; Fomiatti et al. 2014; Gibson et al. 2012; Hoenig et al. 2003; LaPlante and Kaye 2010; Pettersson et al. 2015). For instance, among people using manual/power wheelchairs, scooters, or walkers, the presence of stairs at the entryway was associated with greater difficulty going outside and a reduced number of non-medical visits (Clarke 2014; Hoenig et al. 2003; LaPlante and Kaye 2010). Wheelchair users reporting difficulty getting around outside the home experienced significantly lower levels of social activity, compared to wheelchair users reporting no difficulties getting around outside their home, or persons with disability not using wheelchairs (Carlson and Myklebust 2002). 


\section{Public Buildings \& Homes of Family and Friends}

The accessibility of the physical environment at a destination was equally important as the accessibility in transit to the chosen destination. Reviewed studies emphasized the direct influence of physical barriers to mobility at destinations on social participation of MAT users. For example, accessible settings supported mobility and physical activity among manual wheelchair users (Karmarkar et al. 2011; Tolerico et al. 2007). In contrast, the overall inaccessibility of public buildings or homes of friends and family were major barriers to social participation for all MAT users (Barker, Reid, and Cott 2006; Brandt, Iwarsson, and Ståhle 2004; Carlson and Myklebust 2002; Gibson et al. 2012; Hjelle and Vik 2011; Hoenig et al. 2003; Löfqvist et al. 2009; Meyers et al. 2002; Rosenberg et al. 2013; Wee and Lysaght 2009).

Eighteen studies reported the presence of stairs, doorsteps, heavy doors, and lack of ramps among the barriers faced at destinations by all MAT users. More precisely, thirteen studies reported this barrier for manual and powered wheelchair users (Barker, Reid, and Cott 2006; Brandt, Iwarsson, and Ståhle 2004; Bromley, Matthews, and Thomas 2007; Clarke 2014; Gonzalez and Lord 2015; Hedberg-Kristensson, Ivanoff, and Iwarsson 2007; Hoenig et al. 2003; LaPlante and Kaye 2010; Matthews et al. 2003; Meyers et al. 2002; Pettersson et al. 2015; Rosenberg et al. 2013; Wee and Lysaght 2009), six studies for scooter users (Clarke 2014; Gonzalez and Lord 2015; Hoenig et al. 2007; LaPlante and Kaye 2010; Matthews et al. 2003; Pettersson et al. 2015), and seven studies for cane, walker, and crutch users (Clarke 2014; Gonzalez and Lord 2015; Hedberg-Kristensson, Ivanoff, and Iwarsson 2007; Hoenig et al. 2007; Kylberg et al. 2013; LaPlante and Kaye 2010; Rosenberg et al. 2013).

Inside buildings, barriers such as narrow and/or cluttered aisles, inaccessible shelves, inconsiderate placement of items, and narrow checkouts were identified by all MAT 
users (Bromley, Matthews, and Thomas 2007; Fomiatti et al. 2014; Gonzalez and Lord 2015; Hedberg-Kristensson, Ivanoff, and Iwarsson 2007; Hoenig et al. 2007; Korotchenko and Hurd Clarke 2014; Meyers et al. 2002). Other barriers at destinations for manual/power wheelchair and scooter users included small elevators, which made MAT difficult to maneuver, or absent elevators, and poorly designed, obstructed, or inaccessible washrooms (Barker, Reid, and Cott 2006; Korotchenko and Hurd Clarke 2014; Matthews et al. 2003; Meyers et al. 2002).

\section{Discussion}

\section{Mobility and Social Participation in the Neighborhood}

This systematic literature review highlighted several aspects of the neighborhood physical environment that impedes the mobility and social participation of MAT users. Some factors are reported in multiple studies and across all types of MAT. Not surprisingly, weather, sidewalk and pavement conditions, poor curb cuts, traffic, and inadequate public transportation were important barriers to mobility, and therefore to social participation. Similarly, the inaccessibility of destinations (e.g., public buildings and homes of family and friends) due to the presence of stairs, doorsteps, heavy doors, lack of ramps, narrow or cluttered aisles and checkouts, are some of the many physical barriers at the entrance and inside buildings that affect mobility, and consequently social participation of people using all types of MAT. These results are consistent with studies looking at various users from different age groups and with different abilities which have identified similar barriers to mobility and social participation (Mahmood et al. 2012; Moran et al. 2014; Rosso, Auchincloss, and Michael 2011; Yen et al. 2014).

A noteworthy finding from this systematic review is that the association between neighborhood safety, mixed-land use, residential density, and street connectivity, and the mobility and social participation of MAT users is inconsistent across users and often 
contradictory. These findings differ from other studies with other populations where the influence of certain neighborhood characteristics (street connectivity, mixed land-use, and density) on mobility and social participation appeared to be positive (Mahmood et al. 2012; Villanueva et al. 2014; Yen et al. 2014). One may speculate that variations across other neighborhood characteristics such as population density, limited accessibility, and quality of neighborhood infrastructure may play a role in the divergent results. Additionally, other barriers already identified in the literature (e.g., crowded sidewalks and public transit, traffic congestion, inaccessible shops) may be contributing factors to the influence of neighborhood characteristics in these instances. Additional research is needed to determine what other neighborhood factors in conjunction with street connectivity, neighborhood safety, residential density and mixed land-use contribute to mobility and social participation of MAT users.

Among all of the studies included in the review, no research explored the impact of design features, such as the size of door thresholds and surface level differences on mobility and social participation. These dimensions are important factors for MAT users to enter and exit buildings; however, current literature on social participation and mobility of MAT users does not focus on these environmental aspects. There is a need for empirical studies to explore not only neighborhood features, but also design aspects of entrances to get a holistic perspective on dayto-day mobility of MAT users.

In addition, the majority of the studies included in this review focused on metropolitan or urban environments, while others did not indicate the type of environments in which participants lived. Existing studies regarding disability and rural areas are limited, but suggest that people with disability living in rural context experience additional challenges compared to their urban counterparts (Taub, McLorg, and Bartnick 2009; Levasseur et al. 2015; Therrien and 
Desrosiers 2010; Keating, Swindle, and Fletcher 2011). Based on our findings, it seems that people with mobility disabilities living in rural areas could face unique challenges. For instance, absence of sidewalks and accessible entrances to public buildings could be major obstacles to their mobility and social participation, in comparison to crowded sidewalks and traffic.

\section{Differences Across MAT Users}

Many reviewed studies combined multiple types of MAT. Consequently, it was challenging to identify specific barriers for specific types of MAT. Barriers to mobility and social participation do not affect all MAT users equally. Someone using crutches might be able to overcome a specific physical barrier such as stairs, whereas power wheelchair users could not. Some environmental features could also be facilitators and barriers simultaneously. For example, a downhill slope would be easier to descend in a manual wheelchair (facilitator) but there is also the potential danger for excessive speed (barrier). Individual factors such as the use of multiple devices, health status, caregiver availability, and socio-economic status also need to be taken into account. Future research looking at barriers of mobility and social participation associated with specific types of MAT could nuance these results. More research needs to be conducted with people using MAT to not only highlight factors that are considered barriers, but also to explore the intensity of a barrier and how it affects the use of time and space among each type of MAT user.

A discrepancy was found between the number of studies found for each type of MAT. Twenty-eight out of 30 studies, solely or in combination with other types of MAT, looked at manual wheelchairs, power wheelchairs, and scooters, compared to nine studies looking at walkers and canes. Only two studies included users with crutches in their sample. Consequently, there is limited information regarding relationship among aspects of the neighborhood physical 
environment such as poorly designed crosswalks, traffic congestion, or lack of accessible washrooms and the mobility or social participation of crutch users. Likely, those barriers also affect users with crutches, but their influence has not yet been documented. Similarly, results for walker and cane users need to be interpreted carefully. Future research should focus on identifying features of the neighborhood physical environment that specifically affect the mobility and social participation of users with walkers, canes, and crutches, in comparison to wheelchair and scooter users.

\section{Conceptual Variations}

There were multiple definitions of mobility and social participation, which made comparison across the studies challenging. Mobility was often defined as distance travelled or number of destinations successfully reached. Although these definitions are simple and concrete, they fail to capture the complex experience of mobility and social participation for MAT users. In most of the reviewed studies, social participation was defined as performing activities of everyday life and/or being part of the life of the community. On the one hand, defining social participation as performance of activities of daily life is reductionist, as it overlooks personal and contextual factors, as well as the subjective experience of participation. On the other hand, defining social participation as being part of the life of the community is a broader, but more ambiguous concept that can have different meanings for different people.

Mobility and social participation are complex phenomena and closely related concepts. Participation in instrumental activities of daily life (IADLs) of MAT users, such as grocery shopping or meeting with friends at a local coffee shop, depended on the conditions of the neighborhood physical environment in transit and the accessibility of the final destination. Therefore, the capacity for social participation in the community is conditional on the potential 
for mobility. However, mobility is not always a means to an end. Some may move around their communities without any specific social participation goals in mind and others may mobilize for its kinesthetic pleasure. Unlike other frameworks such as the ICF (World Health Organization 2002), where mobility may be operationalized as either activity or social participation, or both the interrelated nature of mobility and social participation suggests the latter approach should be promoted. Given the interdependent relationship between mobility and social participation among MAT users, there is need for a clearer and more focused discussion on the "mobility-participation" dyad in which both concepts are well defined in a way that considers the experience of MAT users navigating their neighborhoods, but also in the way the two constructs are interrelated. In addition, the role of mobility and social participation as mediating variables on the relationship between the physical environment and the health, quality of life and well-being of this population needs to be further explored.

\section{Study Limitations}

The reviewed studies included diverse methods, objectives, sample characteristics, and ways of measuring mobility and social participation. The results must be interpreted with caution because most quantitative studies were cross-sectional and could only reveal associations. Experimental studies are needed to demonstrate causality between mobility, social participation and neighborhood physical environment factors. With the current research, it is not possible to establish the relative impact of the multiple factors on mobility or social participation among MAT users. In this review, only peer-reviewed publications in English and French were included. Relevant studies in other languages or in grey literature were not included in our search, which may have excluded some relevant information. The descriptions of psychometric properties of measures were sometimes vague, which reduced the credibility of their findings. Study findings 
need to be interpreted in the context of related local, municipal and provincial/state jurisdictions. Finally, many of these studies noted that study participants used more than one assistive device or a combination of MAT to get from destination to destination, or different devices in different types of destinations. Consequently, it was not always possible to identify which environmental factors were associated with which specific types of MAT.

\section{Conclusion}

This systematic literature review showed that multiple factors of the neighborhood physical environment associated with the neighborhood design characteristics (i.e., mixed land use, density, street connectivity, proximity of services), mobility in transit (i.e., weather, sidewalk, and pavement conditions, traffic, parking, transportation), and accessibility of homes and public buildings (i.e., stairs, ramps, heavy doors, accessible washrooms and elevators, narrow aisles) influenced mobility and social participation among people using MAT. Moreover, mobility and social participation are interrelated concepts and need to be analyzed concurrently.

There is great need for future research in this area. The relationship between mobility and social participation in users of different types of MAT needs to be explored. The potential mediating role of mobility and social participation on the relationship between the physical environment and the health, quality of life and well-being of people using MAT required more in-depth examination. Other questions include, "How do MAT users negotiate and manage neighborhood environmental barriers?", and "How does the experience of MAT users affect their daily travels, time management, and travel routes through their neighborhoods?" Methodologically, future research would likely benefit from mixed or multi-methods to facilitate a more comprehensive understanding. Finally, there is a need for intervention research (e.g., 
participatory action research) to generate findings that can effectively inform policies influencing planning and design of responsive neighborhood built environments.

\section{Funding}

BLINDED 


\section{References}

Auger, Claudine, Louise Demers, Isabelle Gelinas, Jeffrey Jutai, Marcus J. Fuhrer, and Frank DeRuyter. 2008. "Powered Mobility for Middle-Aged and Older Adults: Systematic Review of Outcomes and Appraisal of Published Evidence." Journal of Physical Medicine 87 (8): 666-80. https://doi.org/10.1097/PHM.0b013e31816de163.

Auger, Claudine, Louise Demers, Isabelle Gélinas, William C. Miller, Jeffrey W. Jutai, and Luc Noreau. 2010. "Life-Space Mobility of Middle-Aged and Older Adults at Various Stages of Usage of Power Mobility Devices." Archives of Physical Medicine and Rehabilitation 91 (5): 765-73. https://doi.org/10.1016/j.apmr.2010.01.018.

Barker, Donna J., Denise Reid, and Cheryl Cott. 2006. "The Experience of Senior Stroke Survivors: Factors in Community Participation among Wheelchair Users." The Canadian Journal of Occupational Therapy 73 (1): 18-25.

Baum, Carolyn M. 2011. "Fulfilling the Promise: Supporting Participation in Daily Life." Archives of Physical Medicine and Rehabilitation 92 (2): 169-75. https://doi.org/10.1016/j.apmr.2010.12.010.

Botticello, Amanda L., Tanya Rohrbach, and Nicolette Cobbold. 2014. "Disability and the Built Environment: An Investigation of Community and Neighborhood Land Uses and Participation for Physically Impaired Adults." Annals of Epidemiology 24 (7): 545-50. https://doi.org/10.1016/j.annepidem.2014.05.003.

- 2015. "Differences in the Community Built Environment Influence Poor Perceived Health among Persons with Spinal Cord Injury." Archives of Physical Medicine and Rehabilitation 96 (9): 1583-90. https://doi.org/10.1016/j.apmr.2015.04.025.

Brandt, Å., Susanne Iwarsson, and Agneta Ståhle. 2004. “Older People's Use of Powered Wheelchairs for Activity and Participation." Journal of Rehabilitation Medicine 36 (2): 70 77. https://doi.org/10.1080/16501970310017432.

Braun, Virginia, and Victoria Clarke. 2006. "Using Thematic Analysis in Psychology." Qualitative Research in Psychology 3 (2): 77-101. https://doi.org/10.1191/1478088706qp063oa.

Bromley, Rosemary D, David L Matthews, and Colin J Thomas. 2007. "City Centre Accessibility for Wheelchair Users: The Consumer Perspective and the Planning Implications." Cities 24 (3): 229-41. https://doi.org/10.1016/j.cities.2007.01.009.

Carlson, Dawn, and Joel Myklebust. 2002. "Wheelchair Use and Social Integration." Topics in Spinal Cord Injury Rehabilitation 7 (3): 28-46. https://doi.org/10.1310/4VAG-D0BF-QLU5Y1LT.

Centers for Disease Control and Prevention. 2016. "Disability and Health Data System: Disability Estimates: Disability Status and Types.” June 1, 2016. https://dhds.cdc.gov/dataviews/.

Chang, Feng-Hang, Wendy J. Coster, and Christine A. Helfrich. 2013. "Community Participation Measures for People with Disabilities: A Systematic Review of Content from an International Classification of Functioning, Disability and Health Perspective." Archives of Physical Medicine and Rehabilitation 94 (4): 771-81. https://doi.org/10.1016/j.apmr.2012.10.031.

Chaudhury, Habib, Michael Campo, Yvonne Michael, and Atiya Mahmood. 2016. "Neighbourhood Environment and Physical Activity in Older Adults." Social Science \& Medicine 149 (January): 104-13. https://doi.org/10.1016/j.socscimed.2015.12.011.

Clarke, Philippa J. 2014. "The Role of the Built Environment and Assistive Devices for Outdoor 
Mobility in Later Life.” Journals of Gerontology Series B: Psychological Sciences \& Social Sciences 69 (Suppl_1): S8-15. https://doi.org/10.1093/geronb/gbu121.

Clarke, Philippa J., Jennifer A. Ailshire, and Paula Lantz. 2009. "Urban Built Environments and Trajectories of Mobility Disability: Findings from a National Sample of CommunityDwelling American Adults (1986-2001).” Social Science \& Medicine, Part Special Issue: Women, Mothers and HIV Care in Resource Poor Settings, 69 (6): 964-70. https://doi.org/10.1016/j.socscimed.2009.06.041.

Clarke, Philippa J., Jennifer A. Ailshire, Els R. Nieuwenhuijsen, and Marijke W. de Kleijn - de Vrankrijker. 2011. "Participation among Adults with Disability: The Role of the Urban Environment." Social Science \& Medicine 72 (10): 1674-84. https://doi.org/10.1016/j.socscimed.2011.03.025.

Cooper, Rory A., Eliana Ferretti, Michelle Oyster, Annmarie Kelleher, and Rosemarie Cooper. 2011. "The Relationship between Wheelchair Mobility Patterns and Community Participation among Individuals with Spinal Cord Injury.” Assistive Technology 23 (3): 17783. https://doi.org/10.1080/10400435.2011.588991.

Duff, Cameron. 2009. "The Drifting City: The Role of Affect and Repair in the Development of 'Enabling Environments." International Journal of Drug Policy, Risk Environment and Drug Harms, 20 (3): 202-8. https://doi.org/10.1016/j.drugpo.2008.08.002.

Fomiatti, Ryan, Lois Moir, Janet Richmond, and Jeannine Millsteed. 2014. "The Experience of Being a Motorised Mobility Scooter User.” Disability \& Rehabilitation: Assistive Technology 9 (3): 183-87. https://doi.org/10.3109/17483107.2013.814171.

Gell, Nancy M., Dori E. Rosenberg, Jordan Carlson, Jacqueline Kerr, and Basia Belza. 2015. "Built Environment Attributes Related to GPS Measured Active Trips in Mid-Life and Older Adults with Mobility Disabilities." Disability and Health Journal 8 (2): 290-95. https://doi.org/10.1016/j.dhjo.2014.12.002.

Gibson, Barbara E., Barbara Secker, Debbie Rolfe, Frank Wagner, Bob Parke, and Bhavnita Mistry. 2012. "Disability and Dignity-Enabling Home Environments." Social Science \& Medicine 74 (2): 211-19. https://doi.org/10.1016/j.socscimed.2011.10.006.

Giesbrecht, Edward M., Emma M. Smith, W. Ben Mortenson, and William C. Miller. 2017. "Needs for Mobility Devices, Home Modifications and Personal Assistance among Canadians with Disabilities." Health Reports. Ottawa, ON: Statistics Canada.

Gonzalez, Tania, and Sébasting Lord. 2015. "Les Petits et Grands Défis Des Déplacements En Ville Durant La Vieillesse: L'expérience de Personnes Ayant Recours à Des Aides à La Mobilité." Vie et Vieillissement 12 (2): 13-22.

Hammel, Joy, Susan Magasi, Allen Heinemann, David B. Gray, Susan Stark, Pamela Kisala, Noelle E. Carlozzi, David Tulsky, Sofia F. Garcia, and Elizabeth A. Hahn. 2015. "Environmental Barriers and Supports to Everyday Participation: A Qualitative Insider Perspective from People with Disabilities." Archives of Physical Medicine and Rehabilitation 96 (4): 578-88. https://doi.org/10.1016/j.apmr.2014.12.008.

Hansji, Neeraj L., Nathan J. Wilson, and Reinie Cordier. 2015. "Men's Sheds: Enabling Environments for Australian Men Living with and without Long-Term Disabilities." Health \& Social Care in the Community 23 (3): 272-81. https://doi.org/10.1111/hsc.12140.

Hanson, Heather M., Claire Schiller, Meghan Winters, Joanie Sims-Gould, Philippa Clarke, Eileen Curran, Meghan G. Donaldson, et al. 2013. "Concept Mapping Applied to the Intersection between Older Adults' Outdoor Walking and the Built and Social Environments." Preventive Medicine 57 (6): 785-91. https://doi.org/10.1016/j.ypmed.2013.08.023.

Harris, Frances, Hsiang-Yu Yang, and Jon Sanford. 2015. "Physical Environmental Barriers to 
Community Mobility in Older and Younger Wheelchair Users." Topics in Geriatric

Rehabilitation 31 (1): 42-51. https://doi.org/10.1097/TGR.0000000000000043.

Hedberg-Kristensson, Hedberg-Kristensson, SD Ivanoff, and Susanne Iwarsson. 2007.

"Experiences among Older Persons Using Mobility Devices." Disability \& Rehabilitation:

Assistive Technology 2 (1): 15-22.

Hjelle, Kari Margrete, and Kjersti Vik. 2011. "The Ups and Downs of Social Participation:

Experiences of Wheelchair Users in Norway." Disability \& Rehabilitation 33 (25/26): 2479-

89. https://doi.org/10.3109/09638288.2011.575525.

Hoenig, Helen, Lawrence R. Landerman, Kathy M. Shipp, and Linda George. 2003. "Activity

Restriction among Wheelchair Users." Journal of the American Geriatrics Society 51 (9):

1244-51. https://doi.org/10.1046/j.1532-5415.2003.51408.x.

Hoenig, Helen, Carl Pieper, Laurence G. Branch, and Harvey Jay Cohen. 2007. "Effect of

Motorized Scooters on Physical Performance and Mobility: A Randomized Clinical Trial."

Archives of Physical Medicine and Rehabilitation 88 (3): 279-86.

https://doi.org/10.1016/j.apmr.2006.11.022.

Karmarkar, Amol M., Rory A. Cooper, Hongwu Wang, Annmarie Kelleher, and Rosemarie

Cooper. 2011. "Analyzing Wheelchair Mobility Patterns of Community-Dwelling Older

Adults." Journal of Rehabilitation Research \& Development 48 (9): 1077-86.

https://doi.org/10.1682/JRRD.2009.10.0177.

Keating, Norah, Jennifer Swindle, and Stephanie Fletcher. 2011. "Aging in Rural Canada: A

Retrospective and Review." Canadian Journal on Aging/Revue Canadienne Du

Vieillissement 30 (03): 323-38. https://doi.org/10.1017/S0714980811000250.

Kirchner, Corinne E., Elaine G. Gerber, and Brooke C. Smith. 2008. "Designed to Deter:

Community Barriers to Physical Activity for People with Visual or Motor Impairments."

American Journal of Preventive Medicine 34 (4): 349-52.

https://doi.org/10.1016/j.amepre.2008.01.005.

Korotchenko, Alexandra, and Laura Hurd Clarke. 2014. "Power Mobility and the Built

Environment: The Experiences of Older Canadians." Disability \& Society 29 (3): 431-43.

https://doi.org/10.1080/09687599.2013.816626.

Kylberg, Marianne, Charlotte Löfqvist, Judith Phillips, and Susanne Iwarsson. 2013. "Three Very

Old Men's Experiences of Mobility Device Use over Time." Scandinavian Journal of

Occupational Therapy 20 (5): 397-405. https://doi.org/10.3109/11038128.2013.779321.

LaPlante, Mitchell P., and H. Stephen Kaye. 2010. "Demographics and Trends in Wheeled

Mobility Equipment Use and Accessibility in the Community." Assistive Technology 22 (1):

3-17. https://doi.org/10.1080/10400430903501413.

Latham, Alan, Derek McCormack, Kim McNamara, and Donald McNeill. 2009. Key Concepts in

Urban Geography. Thousand Oaks: SAGE Publications, Inc.

Levasseur, Mélanie, Alan A. Cohen, Marie-France Dubois, Mélissa Généreux, Lucie Richard,

France-Hélène Therrien, and Hélène Payette. 2015. "Environmental Factors Associated With

Social Participation of Older Adults Living in Metropolitan, Urban, and Rural Areas: The

NuAge Study." American Journal of Public Health 105 (8): 1718-25.

https://doi.org/10.2105/AJPH.2014.302415.

Levasseur, Mélanie, Lucie Richard, Lise Gauvin, and Émilie Raymond. 2010. "Inventory and

Analysis of Definitions of Social Participation Found in the Aging Literature: Proposed

Taxonomy of Social Activities." Social Science \& Medicine 71 (12): 2141-49.

https://doi.org/10.1016/j.socscimed.2010.09.041.

Liang, Huifang, Kristin Tomey, David Chen, Nina L. Savar, James H. Rimmer, and Carol L. 
Braunschweig. 2008. "Objective Measures of Neighborhood Environment and Self-Reported Physical Activity in Spinal Cord Injured Men." Archives of Physical Medicine and Rehabilitation 89 (8): 1468-73. https://doi.org/10.1016/j.apmr.2008.01.017.

Liberati, Alessandro, Douglas G. Altman, Jennifer Tetzlaff, Cynthia Mulrow, Peter C. Gøtzsche, John P. A. Ioannidis, Mike Clarke, P. J. Devereaux, Jos Kleijnen, and David Moher. 2009. "The PRISMA Statement for Reporting Systematic Reviews and Meta-Analyses of Studies That Evaluate Health Care Interventions: Explanation and Elaboration." PLoS Medicine 6 (7). https://doi.org/10.1371/journal.pmed.1000100.

Löfqvist, C, C Nygren, Brandt Å, and S Iwarsson. 2009. "Very Old Swedish Women's Experiences of Mobility Devices in Everyday Occupation: A Longitudinal Case Study." Scandinavian Journal of Occupational Therapy 16 (3): 181-92. https://doi.org/10.1080/11038120802613108.

Löfqvist, C., C. Pettersson, S Iwarsson, and A. Brandt. 2012. "Mobility and Mobility-Related Participation Outcomes of Powered Wheelchair and Scooter Interventions after 4-Months and 1-Year Use." Disability and Rehabilitation: Assistive Technology 7 (3): 211-18. https://doi.org/10.3109/17483107.2011.619224.

Lord, Sébastien, and Nicolas Luxembourg. 2006. "The Mobility of Elderly Residents Living in Suburban Territories: Mobility Experiences in Canada and France." Journal of Housing for the Elderly 20 (4): 103-21. https://doi.org/10.1300/J081v20n04_07.

Mahmood, Atiya, Habib Chaudhury, Yvonne L. Michael, Michael Campo, Kara Hay, and Ann Sarte. 2012. "A Photovoice Documentation of the Role of Neighborhood Physical and Social Environments in Older Adults' Physical Activity in Two Metropolitan Areas in North America." Social Science \& Medicine 74 (8): 1180-1192. https://doi.org/10.1016/j.socscimed.2011.12.039.

Matthews, Hugh, Linda Beale, Phil Picton, and David Briggs. 2003. "Modelling Access with GIS in Urban Systems (MAGUS): Capturing the Experiences of Wheelchair Users." Area 35 (1): 34-45. https://doi.org/10.1111/1475-4762.00108.

Meyers, Allan R, Jennifer J Anderson, Donald R Miller, Kathy Shipp, and Helen Hoenig. 2002. "Barriers, Facilitators, and Access for Wheelchair Users: Sbstantive and Methodologic Lessons from a Pilot Study of Environmental Effects." Social Science \& Medicine 55 (8): 1435-46. https://doi.org/10.1016/S0277-9536(01)00269-6.

Moher, David, Alessandro Liberati, Jennifer Tetzlaff, and Douglas G. Altman. 2009. "Preferred Reporting Items for Systematic Reviews and Meta-Analyses: The PRISMA Statement." BMJ 339 (July): b2535. https://doi.org/10.1136/bmj.b2535.

Moran, Mika, Jelle Van Cauwenberg, Rachel Hercky-Linnewiel, Ester Cerin, Benedicte Deforche, and Pnina Plaut. 2014. "Understanding the Relationships between the Physical Environment and Physical Activity in Older Adults: A Systematic Review of Qualitative Studies." International Journal of Behavioral Nutrition and Physical Activity 11 (1): 79. https://doi.org/10.1186/1479-5868-11-79.

O’Brien, Elizabeth. 2014. "Planning for Population Ageing: Ensuring Enabling and Supportive Physical-Social Environments - Local Infrastructure Challenges.” Planning Theory \& Practice 15 (2): 220-34. https://doi.org/10.1080/14649357.2014.902986.

Pettersson, Cecilia, Åse Brandt, Eva Månsson Lexell, and Susanne Iwarsson. 2015. "Autonomy and Housing Accessibility among Powered Mobility Device Users." American Journal of Occupational Therapy 69 (5): 1-9. https://doi.org/10.5014/ajot.2015.015347.

Pluye, R., E. Robert, M. Cargo, G. Barlett, A. O’Cathain, F. Griffiths, F. Boardman, M.P. Gagnon, and M.C. Rousseau. 2011. "Proposal: A Mixed Methods Appraisal Tool for 
Systematic Mixed Studies Reviews.” Department of Family Medicine, McGill University, Montreal, Canada. http://mixedmethodsappraisaltoolpublic.pbworks.com.

Rosenberg, Dori E., Deborah L. Huang, Shannon D. Simonovich, and Basia Belza. 2013. "Outdoor Built Environment Barriers and Facilitators to Activity among Midlife and Older Adults with Mobility Disabilities." Gerontologist 53 (2): 268-79.

Rosso, Andrea L., Amy H. Auchincloss, and Yvonne L. Michael. 2011. "The Urban Built Environment and Mobility in Older Adults: A Comprehensive Review." Journal of Aging Research 2011 (June). https://doi.org/10.4061/2011/816106.

Statistics Canada. 2015. "A Profile of Persons with Disabilities among Canadians Aged 15 Years or Older, 2012.” February 25, 2015. http://www.statcan.gc.ca/pub/89-654-x/89-654x2015001-eng.htm\#a12.

- 2016. "Mobility Disabilities among Canadians Aged 15 Years and Older, 2012." Canadian Survey on Disability, 2012. July 5, 2016. http://www.statcan.gc.ca/pub/89-654x/89-654-x2016005-eng.htm.

Taub, Diane E., Penelope A. McLorg, and April K. Bartnick. 2009. "Physical and Social Barriers to Social Relationships: Voices of Rural Disabled Women in the USA." Disability \& Society 24 (2): 201-15. https://doi.org/10.1080/09687590802652496.

Therrien, France-Hélène, and Johanne Desrosiers. 2010. "Participation of Metropolitan, Urban and Rural Community-Dwelling Older Adults." Archives of Gerontology and Geriatrics 51 (3): e52-56. https://doi.org/10.1016/j.archger.2009.11.017.

Tolerico, Michelle L., Dan Ding, Rory A. Cooper, Donald M. Spaeth, Shirley G. Fitzgerald, Rosemarie Cooper, Annmarie Kelleher, and Michael L. Boninger. 2007. "Assessing Mobility Characteristics and Activity Levels of Manual Wheelchair Users." Journal of Rehabilitation Research \& Development 44 (4): 561-72.

Villanueva, Karen, Matthew Knuiman, Andrea Nathan, Billie Giles-Corti, Hayley Christian, Sarah Foster, and Fiona Bull. 2014. "The Impact of Neighborhood Walkability on Walking: Does It Differ across Adult Life Stage and Does Neighborhood Buffer Size Matter?" Health \& Place 25 (January): 43-46. https://doi.org/10.1016/j.healthplace.2013.10.005.

Vine, Desley, Laurie Buys, and Rosemary Aird. 2012. "The Use of Amenities in High Density Neighbourhoods by Older Urban Australian Residents." Landscape and Urban Planning 107 (2): 159-71. https://doi.org/10.1016/j.landurbplan.2012.05.013.

Webber, Sandra C., Michelle M. Porter, and Verena H. Menec. 2010. "Mobility in Older Adults: A Comprehensive Framework." The Gerontologist 50 (4): 443-50. https://doi.org/10.1093/geront/gnq013.

Wee, Joy, and Rosemary Lysaght. 2009. "Factors Affecting Measures of Activities and Participation in Persons with Mobility Impairment.” Disability \& Rehabilitation 31 (20): 1633-42. https://doi.org/10.1080/09638280902736346.

Williams, G., and C. Willmott. 2012. "Higher Levels of Mobility Are Associated with Greater Societal Participation and Better Quality-of-Life.” Brain Injury 26 (9): 1065-71. https://doi.org/10.3109/02699052.2012.667586.

World Health Organization. 2002. "Towards a Common Language for Functioning, Disability and Health: ICF - The International Classification of Functioning, Disability and Health." Geneva: World Health Organization.

- 2011. "World Report on Disability." Geneva: World Health Organization.

Yen, Irene H., Johnna Fandel Flood, Hannah Thompson, Lynda A. Anderson, and Geoff Wong. 2014. "How Design of Places Promotes or Inhibits Mobility of Older Adults: Realist Synthesis of 20 Years of Research.” Journal of Aging and Health 26 (8): 1340-72. 
https://doi.org/10.1177/0898264314527610.

1

2

3

5

6

6

7

8

9

10

11

12

13

14

15

16

17

18

19

20

21

22

23

24

25

26

27

28

29

30

31

32

33

34

35

36

37

38

39

40

41

42

43

44

45

46

47

48

49

50

51

52

53

54

55

56

57

58

59

60 
Figure 1: PRISMA Flowchart - Selection Process of Studies Included in the Review

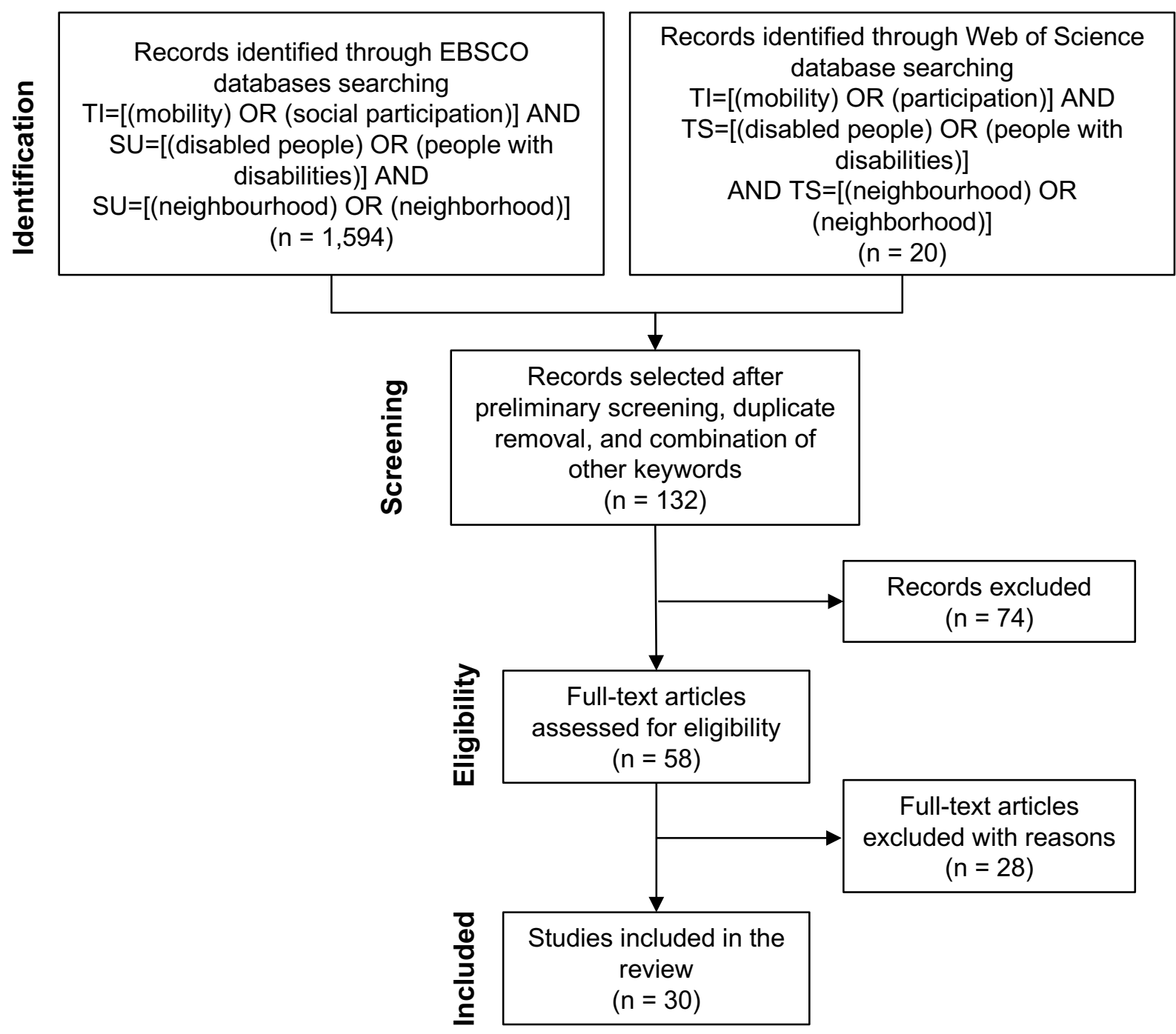


Table 1: Reviewed Studies Details

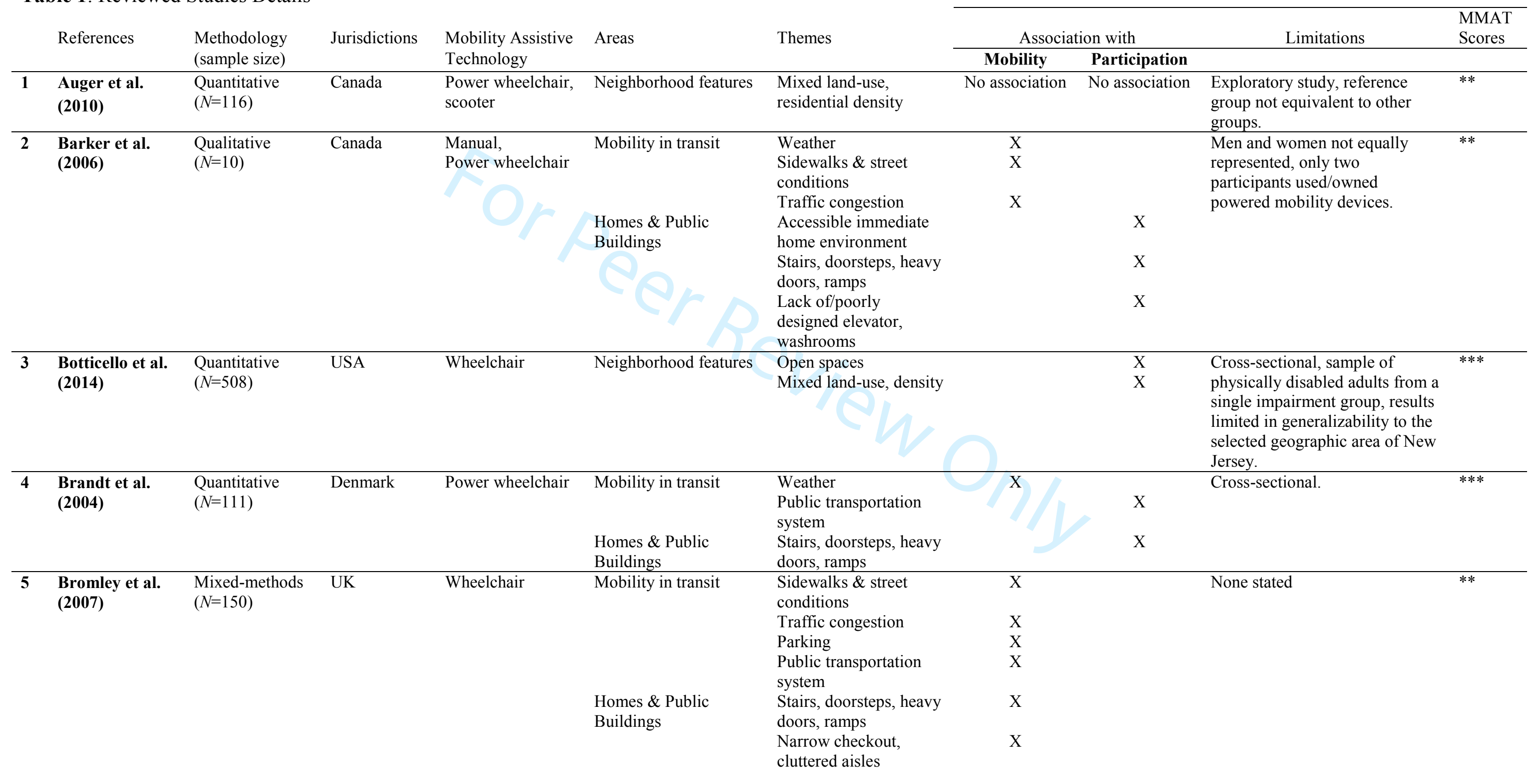




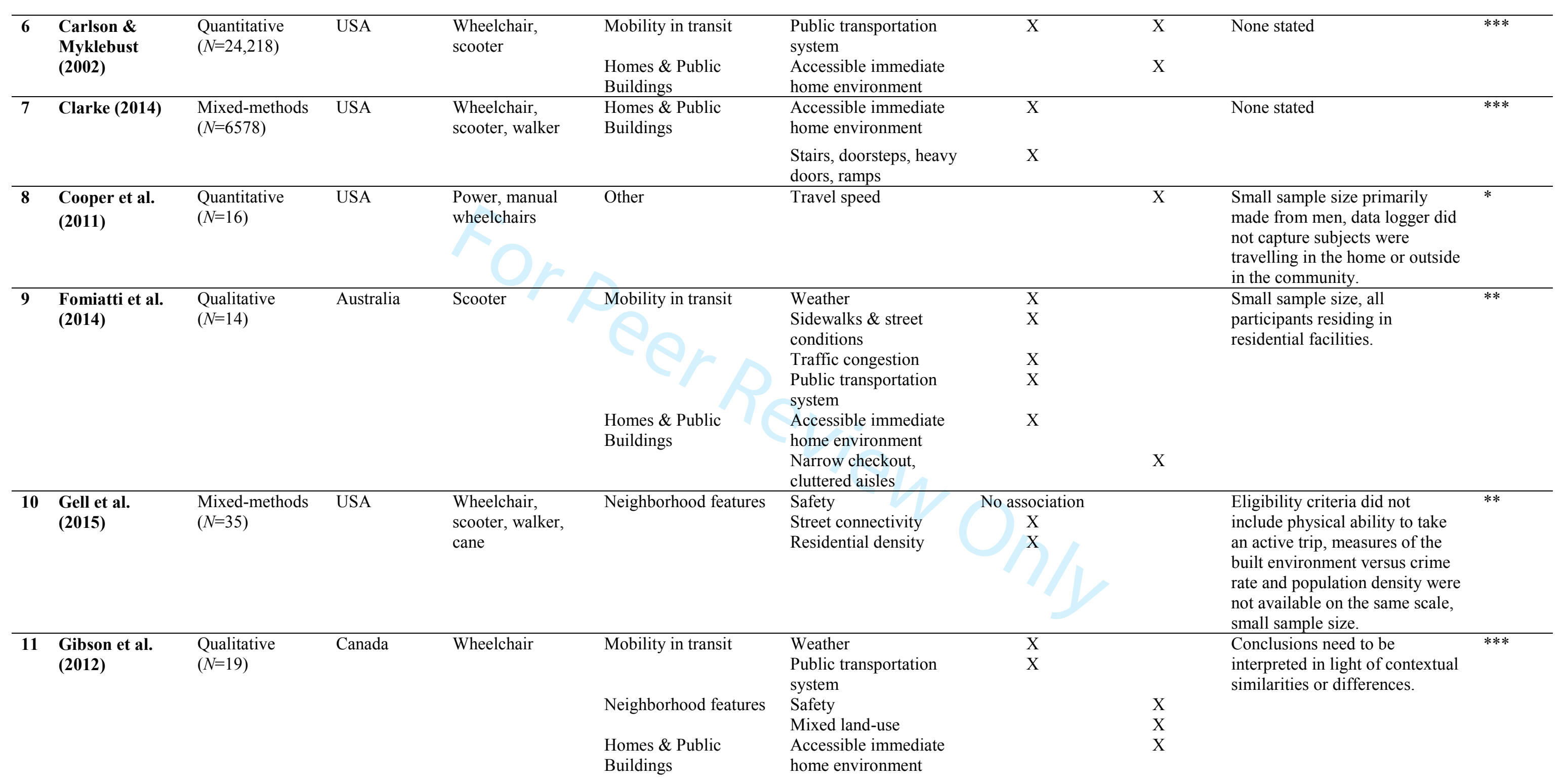




\begin{tabular}{|c|c|c|c|c|c|c|c|c|c|c|}
\hline 12 & $\begin{array}{l}\text { Gonzalez \& } \\
\text { Lord (2015) }\end{array}$ & $\begin{array}{l}\text { Qualitative } \\
(N=8)\end{array}$ & Canada & $\begin{array}{l}\text { Manual, power } \\
\text { wheelchairs, } \\
\text { scooter, walker, } \\
\text { cane }\end{array}$ & $\begin{array}{l}\text { Mobility in transit } \\
\text { Homes \& Public } \\
\text { Buildings }\end{array}$ & $\begin{array}{l}\text { Weather } \\
\text { Public transportation } \\
\text { system } \\
\text { Stairs, doorsteps, heavy } \\
\text { doors, ramps, } \\
\text { Narrow checkout, } \\
\text { cluttered aisles }\end{array}$ & $\begin{array}{l}\mathrm{X} \\
\mathrm{X} \\
\mathrm{X} \\
\mathrm{X}\end{array}$ & & None stated & $* *$ \\
\hline 13 & $\begin{array}{l}\text { Harris et al. } \\
\text { (2015) }\end{array}$ & $\begin{array}{l}\text { Quantitative } \\
(N=385)\end{array}$ & USA & $\begin{array}{l}\text { Manual, power } \\
\text { wheelchairs, } \\
\text { scooter }\end{array}$ & $\begin{array}{l}\text { Mobility in transit } \\
\text { Homes \& Public } \\
\text { Buildings }\end{array}$ & $\begin{array}{l}\text { Sidewalks \& street } \\
\text { conditions } \\
\text { Traffic congestion } \\
\text { Stairs, doorsteps, heavy } \\
\text { doors, ramp }\end{array}$ & $\begin{array}{l}X \\
X\end{array}$ & & None stated & $* *$ \\
\hline 14 & $\begin{array}{l}\text { Hedberg- } \\
\text { Kristensson et } \\
\text { al. (2007) }\end{array}$ & $\begin{array}{l}\text { Qualitative } \\
(N=22)\end{array}$ & Sweden & $\begin{array}{l}\text { Wheelchair, } \\
\text { walker, cane }\end{array}$ & $\begin{array}{l}\text { Mobility in transit } \\
\text { Homes \& Public } \\
\text { Buildings }\end{array}$ & $\begin{array}{l}\text { Weather } \\
\text { Stairs, doorsteps, heavy } \\
\text { doors, ramps } \\
\text { Narrow checkout, } \\
\text { cluttered aisles }\end{array}$ & $\begin{array}{l}X \\
X\end{array}$ & $\begin{array}{l}X \\
X\end{array}$ & $\begin{array}{l}\text { Some of the participants in this } \\
\text { study seemed uncertain and } \\
\text { unaccustomed to taking part in } \\
\text { group discussions. }\end{array}$ & $* * *$ \\
\hline 15 & $\begin{array}{l}\text { Hjelle \& Vik } \\
\text { (2011) }\end{array}$ & $\begin{array}{l}\text { Qualitative } \\
(N=6)\end{array}$ & Norway & Wheelchair & $\begin{array}{l}\text { Mobility in transit } \\
\text { Homes \& Public } \\
\text { Buildings }\end{array}$ & $\begin{array}{l}\text { Sidewalks \& street } \\
\text { conditions } \\
\text { Stairs, doorsteps, heavy } \\
\text { doors, ramps }\end{array}$ & $\mathrm{X}$ & $\mathrm{X}$ & $\begin{array}{l}\text { As participants were recruited } \\
\text { from an association for the } \\
\text { disabled, diversity of the sample } \\
\text { is limited, data from a single } \\
\text { focus group with two } \\
\text { discussions. }\end{array}$ & $* *$ \\
\hline 16 & $\begin{array}{l}\text { Hoenig et al. } \\
\text { (2003) }\end{array}$ & $\begin{array}{l}\text { Quantitative } \\
(N=153)\end{array}$ & USA & $\begin{array}{l}\text { Manual, power } \\
\text { wheelchairs }\end{array}$ & $\begin{array}{l}\text { Mobility in transit } \\
\text { Homes \& Public } \\
\text { Buildings }\end{array}$ & $\begin{array}{l}\text { Public transportation } \\
\text { system } \\
\text { Accessible immediate } \\
\text { home environment } \\
\text { Stairs, doorsteps, heavy } \\
\text { doors, ramps }\end{array}$ & $\mathrm{X}$ & $\mathrm{X}$ & $\begin{array}{l}\text { Convenience sample with } \\
\text { predominantly veteran subjects, } \\
\text { small sample size, the measures } \\
\text { of participation were based on a } \\
\text { 1-week observation of activities. }\end{array}$ & $*$ \\
\hline 17 & $\begin{array}{l}\text { Hoenig et al. } \\
\text { (2007) }\end{array}$ & $\begin{array}{l}\text { Quantitative } \\
(N=43)\end{array}$ & USA & $\begin{array}{l}\text { Scooter, walker, } \\
\text { cane, crutches }\end{array}$ & $\begin{array}{l}\text { Mobility in transit } \\
\text { Homes \& Public } \\
\text { Buildings }\end{array}$ & $\begin{array}{l}\text { Weather } \\
\text { Sidewalks \& street } \\
\text { conditions } \\
\text { Stairs, doorsteps, heavy } \\
\text { doors, ramps } \\
\text { Narrow checkout, } \\
\text { cluttered aisles }\end{array}$ & $\begin{array}{l}X \\
X \\
X \\
X\end{array}$ & & $\begin{array}{l}\text { Data pertaining to the reliability } \\
\text { and validity of the measures of } \\
\text { scooter usage and mobility } \\
\text { methods are limited, study } \\
\text { results may not be generalizable } \\
\text { to people with more severe } \\
\text { disability or with other medical } \\
\text { conditions. }\end{array}$ & $* *$ \\
\hline
\end{tabular}




\begin{tabular}{|c|c|c|c|c|c|c|c|c|c|c|}
\hline 18 & $\begin{array}{l}\text { Karmarkar et } \\
\text { al. (2011) }\end{array}$ & $\begin{array}{l}\text { Quantitative } \\
(N=39)\end{array}$ & USA & $\begin{array}{l}\text { Manual, power } \\
\text { wheelchairs }\end{array}$ & $\begin{array}{l}\text { Homes \& Public } \\
\text { Buildings }\end{array}$ & Accessible environment & & $\mathrm{X}$ & $\begin{array}{l}\text { Convenience sample of older } \\
\text { veterans attending organized } \\
\text { sporting events, data loggers } \\
\text { attached only onto their primary } \\
\text { wheelchairs, data logger could } \\
\text { not make the distinction between } \\
\text { passive and active use of } \\
\text { wheelchair. }\end{array}$ & $*$ \\
\hline 19 & $\begin{array}{l}\text { Kirchner et al. } \\
\text { (2008) }\end{array}$ & $\begin{array}{l}\text { Mixed-methods } \\
(N=134)\end{array}$ & USA & $\begin{array}{l}\text { Manual, power } \\
\text { wheelchairs }\end{array}$ & Mobility in transit & $\begin{array}{l}\text { Weather } \\
\text { Sidewalks \& street } \\
\text { conditions } \\
\text { Traffic congestion }\end{array}$ & $\begin{array}{l}\mathrm{X} \\
\mathrm{X} \\
\mathrm{X}\end{array}$ & & $\begin{array}{l}\text { The sample was small, non- } \\
\text { random, and from one } \\
\text { metropolitan community that is } \\
\text { atypical, especially because it } \\
\text { lacks "car culture." }\end{array}$ & $* * *$ \\
\hline 20 & $\begin{array}{l}\text { Korotchenko \& } \\
\text { Hurd Clark } \\
\text { (2014) }\end{array}$ & $\begin{array}{l}\text { Qualitative } \\
(N=29)\end{array}$ & Canada & $\begin{array}{l}\text { Power wheelchair, } \\
\text { scooter }\end{array}$ & $\begin{array}{l}\text { Mobility in transit } \\
\text { Homes \& Public } \\
\text { Buildings }\end{array}$ & $\begin{array}{l}\text { Sidewalks \& street } \\
\text { conditions } \\
\text { Traffic congestion } \\
\text { Public transportation } \\
\text { system } \\
\text { Stairs, doorsteps, heavy } \\
\text { doors, ramps } \\
\text { Narrow checkout, } \\
\text { cluttered aisles } \\
\text { Lack of/poorly } \\
\text { designed elevator, } \\
\text { washrooms }\end{array}$ & $\begin{array}{l}X \\
X \\
X \\
X \\
X \\
X\end{array}$ & & None stated & $* * *$ \\
\hline 21 & $\begin{array}{l}\text { Kylberg et al. } \\
\text { (2013) }\end{array}$ & $\begin{array}{l}\text { Mixed-methods } \\
(N=3)\end{array}$ & Sweden & Walker, cane & $\begin{array}{l}\text { Mobility in transit } \\
\text { Homes \& Public } \\
\text { Buildings }\end{array}$ & $\begin{array}{l}\text { Weather } \\
\text { Sidewalks \& street } \\
\text { conditions } \\
\text { Stairs, doorsteps, heavy } \\
\text { doors, ramps }\end{array}$ & & $\begin{array}{l}X \\
X\end{array}$ & $\begin{array}{l}\text { Small sample, the experiences } \\
\text { expressed by the three men in } \\
\text { this study cannot be transferred } \\
\text { to very old men in general. }\end{array}$ & $* * *$ \\
\hline 22 & $\begin{array}{l}\text { LaPlante \& } \\
\text { Kaye (2010) }\end{array}$ & $\begin{array}{l}\text { Quantitative } \\
(N=70,311)\end{array}$ & USA & $\begin{array}{l}\text { Manual, power } \\
\text { wheelchairs, } \\
\text { scooter, walker, } \\
\text { canes, crutches }\end{array}$ & $\begin{array}{l}\text { Homes \& Public } \\
\text { Buildings }\end{array}$ & $\begin{array}{l}\text { Sidewalks \& street } \\
\text { conditions } \\
\text { Public transportation } \\
\text { system } \\
\text { Accessible immediate } \\
\text { home environment } \\
\text { Stairs, doorsteps, heavy } \\
\text { doors, ramps }\end{array}$ & $\begin{array}{l}X \\
X \\
X\end{array}$ & & $\begin{array}{l}\text { Different types of wheeled } \\
\text { mobility devices cannot be } \\
\text { distinguished in the analysis, } \\
\text { temporary use of wheel mobility } \\
\text { devices is included but was not } \\
\text { addressed separately in this } \\
\text { study. }\end{array}$ & $* * *$ \\
\hline
\end{tabular}




\begin{tabular}{|c|c|c|c|c|c|c|c|c|c|c|}
\hline 23 & $\begin{array}{l}\text { Liang et al. } \\
(2008)\end{array}$ & $\begin{array}{l}\text { Quantitative } \\
(N=131)\end{array}$ & USA & Wheelchair & Neighborhood features & $\begin{array}{l}\text { Neighborhood safety } \\
\text { Mixed land-use, } \\
\text { Residential density }\end{array}$ & No association & $\begin{array}{c}\mathrm{X} \\
\text { No association }\end{array}$ & $\begin{array}{l}\text { Cross-sectional study, small } \\
\text { sample size, majority of } \\
\text { participants were unemployed, } \\
\text { largely minority group members, } \\
\text { living in urban environments, } \\
\text { self-reported measure of } \\
\text { physical activity. }\end{array}$ & $* *$ \\
\hline 24 & $\begin{array}{l}\text { Löfqvist et al. } \\
\text { (2009) }\end{array}$ & $\begin{array}{l}\text { Mixed-methods } \\
(N=3)\end{array}$ & Sweden & Walker, cane & Mobility in transit & Weather & $\mathrm{X}$ & & $\begin{array}{l}\text { Case studies do not allow } \\
\text { generalizability and participants } \\
\text { were only women. }\end{array}$ & $* * *$ \\
\hline 25 & $\begin{array}{l}\text { Matthews et al. } \\
(2003)\end{array}$ & $\begin{array}{l}\text { Mixed-methods } \\
(N=102)\end{array}$ & UK & $\begin{array}{l}\text { Manual, power } \\
\text { wheelchairs, } \\
\text { scooter }\end{array}$ & $\begin{array}{l}\text { Mobility in transit } \\
\text { Homes \& Public } \\
\text { Buildings }\end{array}$ & $\begin{array}{l}\text { Sidewalks \& street } \\
\text { conditions } \\
\text { Traffic congestion } \\
\text { Parking } \\
\text { Stairs, doorsteps, heavy } \\
\text { doors, ramps } \\
\text { Lack of/poorly } \\
\text { designed elevator, } \\
\text { washrooms } \\
\end{array}$ & $\begin{array}{l}X \\
X \\
X \\
X \\
X\end{array}$ & & None stated & $* * *$ \\
\hline 26 & $\begin{array}{l}\text { Meyers et al. } \\
\text { (2002) }\end{array}$ & $\begin{array}{l}\text { Quantitative } \\
(N=28)\end{array}$ & USA & $\begin{array}{l}\text { Manual, power } \\
\text { wheelchairs }\end{array}$ & $\begin{array}{l}\text { Mobility in transit } \\
\text { Homes \& Public } \\
\text { Buildings }\end{array}$ & $\begin{array}{l}\text { Weather } \\
\text { Sidewalks \& street } \\
\text { conditions } \\
\text { Traffic congestion } \\
\text { Parking } \\
\text { Public transportation } \\
\text { system } \\
\text { Stairs, doorsteps, heavy } \\
\text { doors, ramps } \\
\text { Narrow checkout, } \\
\text { cluttered aisles } \\
\text { Lack of/poorly } \\
\text { designed elevator, } \\
\text { washrooms }\end{array}$ & $\begin{array}{l}X \\
X \\
X \\
X \\
X \\
X \\
X \\
X \\
X\end{array}$ & & $\begin{array}{l}\text { Opportunistic sample, consisting } \\
\text { mostly of highly active and } \\
\text { highly engaged people, the study } \\
\text { was of relatively short duration } \\
\text { and took place in a limited } \\
\text { number of locales. }\end{array}$ & **** \\
\hline 27 & $\begin{array}{l}\text { Pettersson et al. } \\
\text { (2015) }\end{array}$ & $\begin{array}{l}\text { Quantitative } \\
(N=48)\end{array}$ & Sweden & $\begin{array}{l}\text { Power wheelchair, } \\
\text { scooter }\end{array}$ & $\begin{array}{l}\text { Mobility in transit } \\
\text { Homes \& Public } \\
\text { Buildings }\end{array}$ & $\begin{array}{l}\text { Sidewalks \& street } \\
\text { conditions } \\
\text { Accessible immediate } \\
\text { home environment } \\
\text { Stairs, doorsteps, heavy } \\
\text { doors, ramps }\end{array}$ & & $\begin{array}{l}X \\
X \\
X\end{array}$ & $\begin{array}{l}\text { Heterogeneous group, results } \\
\text { might not be generalizable to all } \\
\text { PMD users, only objective } \\
\text { measures, Housing ENABLER } \\
\text { does not take into account } \\
\text { specific function and } \\
\text { characteristics of newer PMD. }\end{array}$ & $* * *$ \\
\hline
\end{tabular}




\begin{tabular}{|c|c|c|c|c|c|c|c|c|c|c|}
\hline 28 & $\begin{array}{l}\text { Rosenberg et } \\
\text { al. (2013) }\end{array}$ & $\begin{array}{l}\text { Qualitative } \\
(N=35)\end{array}$ & USA & $\begin{array}{l}\text { Manual, power } \\
\text { wheelchairs, cane, } \\
\text { walker }\end{array}$ & $\begin{array}{l}\text { Mobility in transit } \\
\text { Neighborhood features } \\
\text { Homes \& Public } \\
\text { Buildings }\end{array}$ & $\begin{array}{l}\text { Weather } \\
\text { Sidewalks \& street } \\
\text { conditions } \\
\text { Traffic congestion } \\
\text { Parking } \\
\text { Safety } \\
\text { Stairs, doorsteps, heavy } \\
\text { doors, ramps }\end{array}$ & $\begin{array}{l}\mathrm{X} \\
\mathrm{X} \\
\mathrm{X} \\
\mathrm{X}\end{array}$ & $\begin{array}{l}X \\
X\end{array}$ & $\begin{array}{l}\text { Lack of recording and } \\
\text { transcribing interviews, } \\
\text { interviews took place during the } \\
\text { winter and spring in urban and } \\
\text { suburban settings. }\end{array}$ & $* * *$ \\
\hline 29 & $\begin{array}{l}\text { Tolerico et al. } \\
\text { (2007) }\end{array}$ & $\begin{array}{l}\text { Quantitative } \\
(N=52)\end{array}$ & USA & $\begin{array}{l}\text { Manual } \\
\text { wheelchair }\end{array}$ & $\begin{array}{l}\text { Homes \& Public } \\
\text { Buildings }\end{array}$ & Accessible environment & & $\mathrm{X}$ & $\begin{array}{l}\text { Data loggers attached only onto } \\
\text { their primary wheelchairs, data } \\
\text { logger could not make the } \\
\text { distinction between passive and } \\
\text { active use of wheelchair. }\end{array}$ & $*$ \\
\hline 30 & $\begin{array}{l}\text { Wee \& Lysaght } \\
(2009)\end{array}$ & $\begin{array}{l}\text { Mixed-methods } \\
(N=24)\end{array}$ & Canada & Wheelchair & $\begin{array}{l}\text { Mobility in transit } \\
\text { Homes \& Public } \\
\text { Buildings }\end{array}$ & $\begin{array}{l}\text { Weather } \\
\text { Public transportation } \\
\text { system } \\
\text { Stairs, doorsteps, heavy } \\
\text { doors, ramps }\end{array}$ & & $\begin{array}{l}X \\
X \\
X\end{array}$ & $\begin{array}{l}\text { Small sample size, exclusion of } \\
\text { participants living in nursing } \\
\text { home settings. }\end{array}$ & $* * *$ \\
\hline
\end{tabular}


Table 2: Themes Found per Type of MAT

\begin{tabular}{|c|c|c|c|c|c|c|c|c|}
\hline & & & $\begin{array}{c}\text { Manual } \\
\text { Wheelchair }\end{array}$ & $\begin{array}{c}\text { Power } \\
\text { Wheelchair }\end{array}$ & Scooter & Walker & Cane & Crutches \\
\hline \multirow{5}{*}{$\begin{array}{l}\text { Neighborhood } \\
\text { Features }\end{array}$} & \multicolumn{2}{|l|}{ Open spaces } & $\bullet$ & $\bullet$ & $\mathrm{X}$ & $\mathrm{X}$ & $\mathrm{X}$ & $\mathrm{X}$ \\
\hline & \multicolumn{2}{|l|}{ Safety } & 0 & 0 & 0 & 0 & 0 & $\mathrm{X}$ \\
\hline & \multicolumn{2}{|l|}{ Mixed land-use } & 0 & 0 & 0 & - & - & $\mathrm{X}$ \\
\hline & \multicolumn{2}{|c|}{ Residential density } & 0 & 0 & - & - & - & $\mathrm{X}$ \\
\hline & \multicolumn{2}{|c|}{ Street connectivity } & 0 & 0 & 0 & - & - & $\mathrm{X}$ \\
\hline \multirow{11}{*}{$\begin{array}{l}\text { Mobility in } \\
\text { Transit }\end{array}$} & \multicolumn{2}{|c|}{ Weather } & - & - & - & - & - & - \\
\hline & \multirow{4}{*}{$\begin{array}{l}\text { Sidewalks \& } \\
\text { street conditions }\end{array}$} & Sidewalks/pavement & - & - & - & - & - & - \\
\hline & & Curb cuts & - & - & - & - & - & - \\
\hline & & Crosswalks & - & - & - & - & - & $\mathrm{X}$ \\
\hline & & Temporary obstacles & $\bullet$ & $\bullet$ & $\bullet$ & $\bullet$ & $\bullet$ & $\mathrm{X}$ \\
\hline & \multirow[t]{2}{*}{ Traffic congestion } & Vehicular traffic & $\bullet$ & $\bullet$ & $\bullet$ & $\bullet$ & $\bullet$ & $\mathrm{X}$ \\
\hline & & Pedestrian traffic & - & - & - & $\mathrm{X}$ & $\mathrm{X}$ & $\mathrm{X}$ \\
\hline & \multicolumn{2}{|l|}{ Parking } & - & - & - & - & - & $\mathrm{X}$ \\
\hline & \multirow{3}{*}{$\begin{array}{l}\text { Public } \\
\text { transportation } \\
\text { system }\end{array}$} & Space to maneuver & $\mathrm{X}$ & $\mathrm{X}$ & $\bullet$ & $\bullet$ & $\bullet$ & $\mathrm{X}$ \\
\hline & & Service availability & 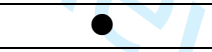 & 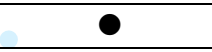 & $\bullet$ & $\bullet$ & $\bullet$ & $\mathrm{X}$ \\
\hline & & $\begin{array}{l}\text { Accessibility of stops, } \\
\text { stations, buses, trains }\end{array}$ & $\bullet$ & $\bullet$ & $\bullet$ & $\bullet$ & $\bullet$ & $\bullet$ \\
\hline \multirow{4}{*}{$\begin{array}{l}\text { Homes \& } \\
\text { Public } \\
\text { Buildings }\end{array}$} & $\begin{array}{l}\text { Immediate home } \\
\text { environment }\end{array}$ & $\begin{array}{l}\text { Accessibility of exit and } \\
\text { entrance }\end{array}$ & - & & - & - & - & - \\
\hline & \multirow{3}{*}{$\begin{array}{l}\text { Public buildings } \\
\& \text { homes of } \\
\text { family and friends }\end{array}$} & $\begin{array}{l}\text { Stairs, doorsteps, heavy } \\
\text { doors, ramp }\end{array}$ & - & - & - & $\bullet$ & - & • \\
\hline & & $\begin{array}{l}\text { Narrow checkout, } \\
\text { cluttered aisles }\end{array}$ & $\bullet$ & - & • & $\bullet$ & $\bullet$ & $\bullet$ \\
\hline & & $\begin{array}{l}\text { Lack of/poorly designed } \\
\text { elevator, washroom }\end{array}$ & $\bullet$ & $\bullet$ & - & $X$ & $\mathrm{X}$ & $\mathrm{X}$ \\
\hline
\end{tabular}

Note 1: $\boldsymbol{O}=$ Association; $\boldsymbol{O}=$ Mixed results; $X=$ No study found 